\title{
Toxic metal enrichment and boating intensity: sediment records of antifoulant copper in shallow lakes of eastern England
}

\author{
John F. Boyle $\cdot$ Carl D. Sayer • Dan Hoare • \\ Helen Bennion - Kate Heppel - Stephen J. Lambert • \\ Peter G. Appleby • Neil L. Rose • Anthony J. Davy
}

Received: 14 October 2014/ Accepted: 6 November 2015/Published online: 8 February 2016

(C) The Author(s) 2016. This article is published with open access at Springerlink.com

\begin{abstract}
Tributyltin (TBT), an aqueous biocide derived from antifouling paint pollution, is known to have impacted coastal marine ecosystems, and has been reported in the sediment of the Norfolk and Suffolk Broads, a network of rivers and shallow lakes in eastern England. In the marine environment, the 1987 TBT ban resulted in expanded use of alternative biocides, raising the question of whether these products too have impacted the Broads ecosystem and freshwaters in general. We examined the lake sediment record in the Norfolk and Suffolk Broads for contamination by copper $(\mathrm{Cu})$, an active biocide agent,
\end{abstract}

J. F. Boyle $(\bowtie)$

Department of Geography and Planning, University of Liverpool, Roxby Building, Myrtle Street,

Liverpool L69 7ZT, UK

e-mail: jfb@liv.ac.uk

C. D. Sayer - H. Bennion - N. L. Rose

Environmental Change Research Centre, Department of Geography, University College London, Gower Street,

London WC1E 6BT, UK

e-mail: c.sayer@ucl.ac.uk

H. Bennion

e-mail: h.bennion@ucl.ac.uk

N. L. Rose

e-mail: n.rose@ucl.ac.uk

D. Hoare

Broads Authority, Yare House, 62-64 Thorpe Road,

Norwich NR1 1RY, UK

e-mail:dan.hoare@broads-authority.gov.uk and zinc ( $\mathrm{Zn})$, a component of booster biocides, to assess their occurrence and potential for causing environmental harm in freshwater ecosystems. After the introduction of leisure boating, there was a statistically significant difference in $\mathrm{Cu}$ enrichment between heavily and lightly boated sites, whereas no such difference existed prior to that time. At the heavily boated sites, the onset of $\mathrm{Cu}$ enrichment coincided with a period of rapid increase in leisure boating. Such enrichment has been maintained to the present day, with some evidence of continued increase. We conclude that $\mathrm{Cu}$-based antifouling has measurably contaminated lakes exposed to boating, at

K. Heppel

School of Geography, Queen Mary University of London, Mile End Road, London E1 4NS, UK

e-mail: c.m.heppell@qmul.ac.uk

S. J. Lambert · A. J. Davy

School of Biological Sciences, Norwich Research Park, University of East Anglia, Norwich NR4 7TJ, UK e-mail: stephen.lambert@uea.ac.uk

A. J. Davy

e-mail: a.davy@uea.ac.uk

P. G. Appleby

Department of Mathematical Sciences, University of

Liverpool, Roxby Building, Myrtle Street,

Liverpool L69 7ZT, UK

e-mail: appleby@liv.ac.uk 
concentrations high enough to cause ecological harm. Similar findings can be expected at other boated freshwater ecosystems elsewhere in the world.

Keywords Freshwater - Antifouling paint - Copper · TBT $\cdot$ Lake sediment $\cdot$ Pollution

\section{Introduction}

Marine commercial shipping and leisure craft employ antifouling paints to reduce drag by keeping their hulls clear of biota. The toxic agents contained in these paints were first observed in nature during the 1970s, and since then numerous studies have been undertaken in coastal marine environments (Dahl and Blanck 1996; Voulvoulis et al. 2000; Callow and Callow 2002; Thomas and Brooks 2010; Eklund et al. 2010, 2014; Marcheselli et al. 2010; Parks et al. 2010; Ytreberg et al. 2010; Tsunemasa and Yamazaki 2014), documenting the extent and impact of the contamination. The same agents have also been found in freshwater systems. In the 1980s, Canadian freshwater environments connected with marine shipping were found to have toxic concentrations of TBT (Maguire et al. 1986), and in Lake Lucerne, Switzerland, substantial concentrations of antifouling organotins (including TBT) were found in the water and sediments at marinas (Fent and Hunn 1991). In the Norfolk Broads (East Anglia, eastern England), a network of small, shallow lakes and rivers partially connected with the sea, lake and river sediments were also found to contain TBT in 1989, the levels of which fell substantially by 1992 (Dowson et al. 1994). Despite the significance of these reports, only a few subsequent investigations (Sayer et al. 2006; Lambert et al. 2006; Hoare 2007) considered the extent and impact of environmental pollution by antifouling paints in UK freshwater ecosystems. Sayer et al. (2006) showed that the Norfolk Broads contain a coherent sediment record of the since-banned biocide, TBT. The TBT record is consistent with its historical use, first appearing in the 1960s and then rapidly declining after the 1987 UK ban from vessels $<25 \mathrm{~m}$ long. The onset of TBT contamination in the Norfolk Broads was coincident with palaeoecological evidence for ecosystem degradation in the form of macrophyte loss and changes in associated invertebrate communities. This, in conjunction with background eutrophication forcing, is suspected to have contributed to the transformation of the lakes from clear-water, macrophyte-dominated to turbid, algal-dominated conditions (Sayer et al. 2006; Holmes et al. 2010).

But what is the effect of other antifouling paint biocides in this freshwater system? TBT was banned in 1987, yet there is no sign of a return to clear-water, macrophyte-dominated conditions in the boated Broads system. This is most likely a consequence of the continued influence of eutrophication, but it is also possible that TBT-replacement antifouling agents are contributing to ecological degradation, and in turn, to poor/slow recovery in the Broads. Indeed there is some evidence consistent with this in the case of the organic antifouling biocide Irgarol 1051 (N-2-methylthio-4-tert-butylamino-6-cyclopropylamino-s-triazine), its metabolite GS26575 (2-methylamino-4-tert-butylamino-6-amino-s-triazine) and diuron (1-(3,4-dichlorophenyl)-3,3-dimethylurea), which were reported by Lambert et al. (2006) to be persistently present in the water of seven broads. The measured environmental concentrations were demonstrated in the laboratory to damage both algal and angiosperm aquatic macrophyte species previously common to the broads surveyed (Lambert et al. 2006). There is still a global market for, and use of these products as booster biocides (i.e. compounds added to an antifoulant to increase efficacy), though since 2001 they have been banned within the UK. Copper is nevertheless widely used as an agent in antifoulants, and a number of organozinc compounds (e.g. zinc pyrithione and zineb) are still in use as booster biocides. Copper is a particular concern in the Broads ecosystems, as correlations have been observed in Hickling Broad between sediment $\mathrm{Cu}$ concentrations and measures of photosynthetic stress in the important and now much depleted charophyte community (Smith 2003; Evans 2004). Investigating possible source links, Smith (2003) also analysed interstitial waters in sediments and found that $\mathrm{Cu}$ concentrations diminished linearly with distance from the central boating channel. Furthermore, Lambert (2007) found that concentrations of $\mathrm{Cu}$ equal to those recorded in the interstitial waters at Hickling Broad in 2005 could be demonstrated to cause a significant reduction in charophyte rhizoid growth when tested under laboratory conditions. These investigations establish a clear link between $\mathrm{Cu}$ enrichment and the probability of 
environmental harm, but do not directly address the source of the $\mathrm{Cu}$ contamination.

In this study we tested the possibility that boat antifouling paints are the primary $\mathrm{Cu}$ source to the Broads freshwater lakes. That $\mathrm{Cu}$ is supplied to the environment by such paints is beyond question: it is an active ingredient, released slowly into the water adjacent to the hull (Dahl and Blanck 1996). It is not, however, straightforward to estimate the relative importance of this pathway in the presence of possible alternative sources. In our study, we examined the sediment records of nine lakes in the Norfolk and Suffolk Broads, assessing temporal changes in the sediment concentrations of $\mathrm{Cu}$ (as a biocide agent in its own right), and $\mathrm{Zn}$ (as a measure of organo-zinc booster biocides). Four of the lakes are heavily boated and five are either boat-free or only very lightly boated. If boating is a significant source of $\mathrm{Cu}$ and $\mathrm{Zn}$, then for sediment deposited since the introduction of leisure boating there should be relative metal enhancement at heavily boated sites. For sediment deposited before that time, any metal enrichment should be independent of boating intensity.

\section{Coring sites and sampling}

The Norfolk and Suffolk Broads comprise 60 small (0.01-1.41 km², median $0.046 \mathrm{~km}^{2}$ ), shallow (generally $<2 \mathrm{~m}$ water depth) lakes (termed broads) in eastern England. A $303-\mathrm{km}^{2}$ part of the area was given National Park status in 1989, and large parts of the area are internationally recognised as the Broadland Ramsar site, and as part of the European Natura 2000 network (The Broads Special Area of Conservation). The broads are flooded medieval peat workings, situated in the valleys of five rivers that converge at the town of Great Yarmouth before discharging into the North Sea (Fig. 1). From the late nineteenth century, the rivers and lakes of the Broads system have formed an important centre for recreational boating (George 1992). Some of the broads are navigable and directly connected to the main river system, whereas others are isolated and are not used by leisure craft. The nine broads included in the current study (Fig. 1) were chosen to represent these two usage categories. Four of the sites are connected to main rivers (Barton Broad, Wroxham Broad, Salhouse Great Broad and Hickling Broad) and are used by boats that employ antifouling paints, whereas five of the sites (Ormesby
Great Broad, Ormesby Little Broad, Woolner's Carr, Sprat's Water, Barnby Broad) are wholly or partially isolated from the main river system. The broads are alkaline lakes and most, especially the connected broads, are eutrophic and characterised by an absence of submerged macrophytes and prevalence of dense phytoplankton populations (Moss 2001). The sediment in all nine broads comprises a homogeneous mixture of calcareous and organic detritus, with lesser amounts of terrigenous mineral matter, typically with 60-200 cm of sediment lying directly above cut peat surfaces (Ayres et al. 2008; Madgwick et al. 2011).

\section{Materials and methods}

\section{Sites}

Figure 1 shows the location of the study sites. The heavily boated sites (Barton, Hickling, Salhouse Great and Wroxham Broads) were selected as the largest navigable open water bodies in the upper reaches of three Broadland rivers. The lightly boated sites, all wholly or partially isolated from the navigable rivers, were selected from the Trinity Broads catchment (Ormesby Little and Great Broads) and the Waveney Valley (Barnby Broad, Sprat's Water and Woolner's Carr). A single core was collected from each site, from open water locations at least $30-40 \mathrm{~m}$ from the lake edge, with evidence for deep-water sediment accumulation.

\section{Sediment coring}

Sediment cores were collected using an adapted fat (74-mm i.d.) Livingstone coring system (Livingston 1955), with the exception of the core from Salhouse Great Broad, which was extracted using a wide-bore (140-mm i.d.) Big Ben piston-corer (Patmore et al. 2014). Coring dates, core lengths, sampling intervals, and the chemical analytical methods that were applied are given in Table 1.

\section{Sediment dating}

Seven of the nine cores were dated using ${ }^{210} \mathrm{~Pb}$ and

${ }^{137} \mathrm{Cs}$. The radionuclides were measured by gamma assay using Ortec HPGe GWL series well-type germanium detectors at the University of Liverpool 
(Appleby et al. 1986). Two of the cores were dated using their sediment records of spheroidal carbonaceous particles (SCP). SCP analysis followed Rose (1994, 2008), while dating followed Rose et al. (1995), comparing features in the profiles with the known record. Radiometric dating followed Appleby et al. (1986), by integrating chronological information from bomb testing ${ }^{137} \mathrm{Cs}$ with the decay profiles for naturally occurring unsupported ${ }^{210} \mathrm{~Pb}$. Dating models, and either radionuclide activities or SCP concentrations, are shown in Fig. 2.

Analytical methods

Metal concentrations were determined by either X-ray fluorescence analysis (XRF) (Boyle 2000) or atomic absorption spectrometry (AAS) on nitric acid extracts. XRF analysis was undertaken using a Bruker S2
Ranger energy dispersive XRF analyser, with calibration and quality control based on a suite of 20 certified reference materials (Table 2).

Standard errors of regression for the reference material (of certified values against measured values, measured as unknowns) for $\mathrm{Cu}, \mathrm{Pb}$ and $\mathrm{Zn}$ were 2.9, 2.7 and $2.2 \mathrm{ppm}$, respectively. AAS measurements were undertaken using a Unicam 939 Atomic Absorption Spectrophotometer. Sediment was dried at $40{ }^{\circ} \mathrm{C}$. Approximately $0.5 \mathrm{~g}$ quantities were weighed accurately and placed in 60-ml high-temperature polythene tubes. $2 \mathrm{ml}$ concentrated AnalR nitric acid was added. When initial reaction had ceased, the tubes were heated at $90{ }^{\circ} \mathrm{C}$ for $1 \mathrm{~h}$. When cool, the samples were made up to $24 \mathrm{ml}$ using $10 \% \mathrm{HCl}$. These were centrifuged and decanted. Based on partial extraction from the sediment, AAS-measured concentration values are generally lower than those obtained by
Fig. 1 Site map with locations, blow-ups of each site with coring location, plus major roads and cities, and major channels

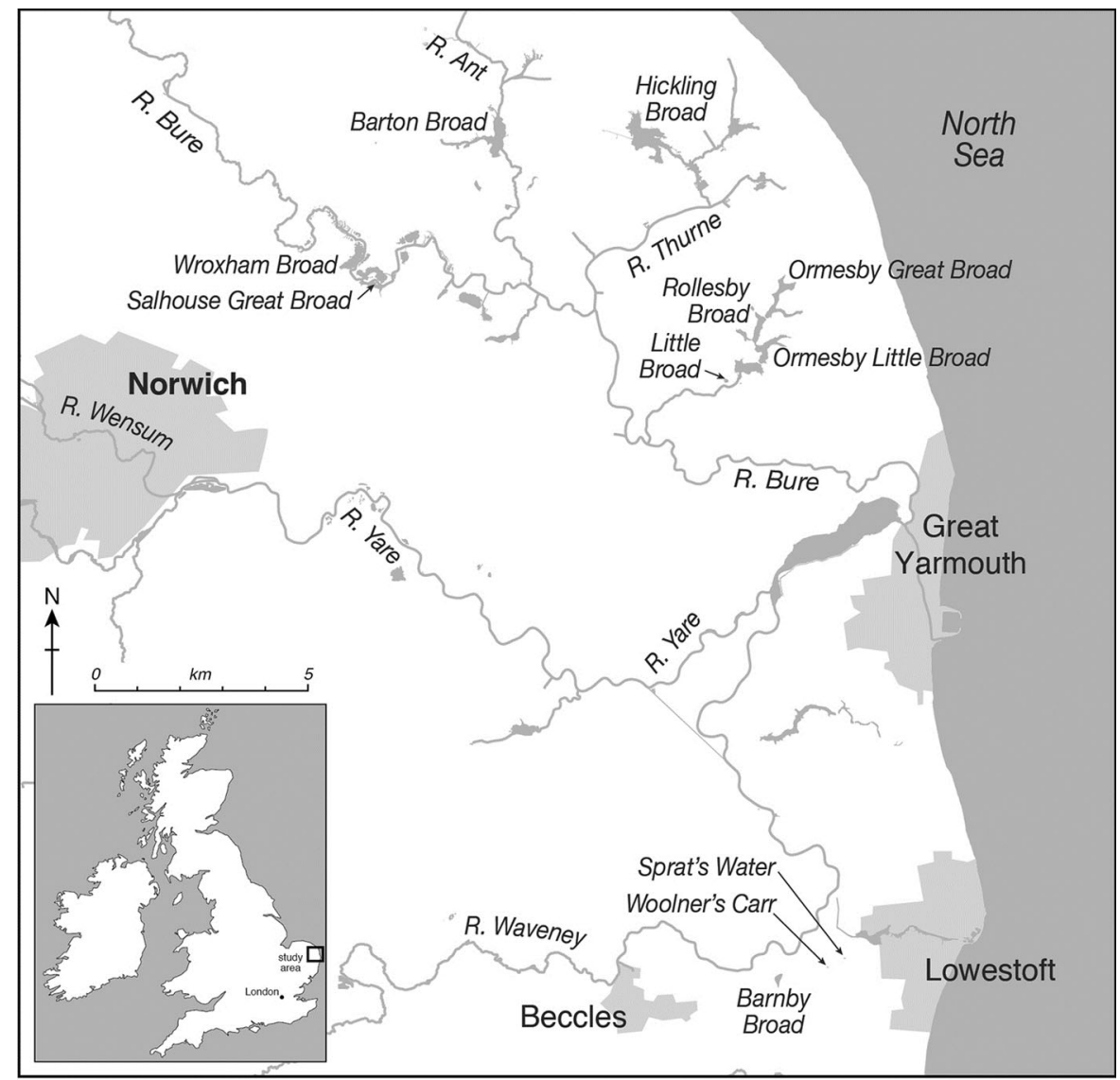

Map data (C) OpenStreetMap contributors, CC-BY-SA 
XRF (Boyle 2001b). This effect is generally weakest for $\mathrm{Pb}$ and strongest for $\mathrm{Cu}$. We have no measurement of the magnitude of the effect in our samples, but expect it does not exceed $20 \mathrm{ppm}$. Such a difference has little impact on the interpretation of the metal profiles, which depends as much on within-core stratigraphic change as between-core differences.

Organic matter concentration was measured by loss on ignition (LOI). Weight loss was measured after $1 \mathrm{~h}$ of ignition at $550{ }^{\circ} \mathrm{C}$ on sediment previously dried at $105^{\circ} \mathrm{C}$. Sediment dry density was measured on $1-\mathrm{cm}^{3}$ subsamples.

We assume that concentrations of $\mathrm{Cu}, \mathrm{Pb}$ and $\mathrm{Zn}$ were not influenced by post-depositional remobilisation, as the mass accumulation rates were sufficient for dissolved fluxes within the sediment to be negligible (Boyle 2001a). We assume that the total metal concentration is made up of the cumulative contributions from natural sources, atmospheric deposition and runoff pollution, and any release from boat antifouling materials. Lastly, we also assume that no analytical procedure can discriminate between these sources, and rely instead on differences in total element concentration between heavily boated and lightly boated sites to infer the relative importance of the different potential sources of metals.

Organotin compounds (tributyltin, dibutyltin and monobutyltin) were analysed by gas chromatography with flame photometric detection, following extraction by sodium hydroxide and methanol, conversion to hydride, and partitioning into hexane (Waldock and Waite 1994). These were measured at only three sites: Wroxham, Hickling and Salhouse Great Broads.

\section{Boating intensity}

The sites were divided into two categories, heavily versus lightly boated. No data exist on boat usage for specific sites. Our distinction thus rests on the nature of the sites. Three of the four heavily boated sites, Wroxham Broad, Hickling Broad and Barton Broad have boat yards situated on them, and all are connected to the navigable rivers. The fourth, Salhouse Great Broad, is adjacent to the River Bure and receives very heavy leisure boat traffic. In the lightly boated category, the two Ormesby Broads are used by rowing and sailing boats, which are moored on site. The other three broads have no boating at all, and are fully isolated from the river network.
To measure temporal change in boating intensity we used boat count data (unpublished database, Broads Authority), which are available from 1959 to the present. Data are available for total boat numbers and for total motorboats. We used the latter as most non-motored craft (including small rowing and sailing boats that are stored out of water) do not use antifouling paints, and we assumed that total motorboat number, comprising $69 \%$ of the total boat count (average since 1959) is proportional to the larger craft that do employ such paints. There are no quantitative data on boat numbers for years prior to 1959 . Consequently, direct statistical testing of temporal association between boat count and sediment $\mathrm{Cu}$ or $\mathrm{Zn}$ concentration is not possible. On the other hand, we know that boat count increased rapidly from the start of the record, doubling in the first 8 years and then remaining relatively constant. If we assume that prior to 1959 the boat count was low, then we can statistically test the impact of boats by dividing the record into early (low boat numbers) and late (high boat numbers) intervals. 1960 was chosen as the dividing date as it is mid-way through the period of most rapid boat number increase.

\section{Results}

Before describing the sediment records, the significance of strong enrichment of $\mathrm{Cu}$ and $\mathrm{Zn}$ in surficial sediment must be addressed. Apparent most strikingly at Hickling and Barton Broads, we attribute this to temporary metal storage in the surficial floc layer. Reviewed by Boyle (2000), this commonly observed phenomenon represents only a small quantity of metal, the high concentration reflecting the low dry-matter content of the uppermost sediment rather than high metal contents. These surface enrichments contribute little to the total metal flux (Boyle 2000), and are here considered negligible.

The sediment concentration records of TBT, $\mathrm{Cu}, \mathrm{Pb}$ and $\mathrm{Zn}$ (Fig. 3) reveal a general pattern of early increase and later decrease. In detail, however, the four substances reveal distinctly different temporal trends. The TBT concentration record (measured only at Hickling, Salhouse Great and Wroxham Broads) differs greatly from the metals, being absent prior to ca. 1960. After that date, the concentration builds rapidly to a maximum. High values are maintained 
Table 1 Site and sediment core details

\begin{tabular}{|c|c|c|c|c|c|c|c|c|c|c|}
\hline Site name Core code & $\begin{array}{l}\text { Latitude N } \\
\text { longitude E, } \\
\text { degrees }\end{array}$ & $\begin{array}{l}\text { Coring } \\
\text { date }\end{array}$ & $\begin{array}{l}\text { Water } \\
\text { depth } \\
\mathrm{m}\end{array}$ & $\begin{array}{l}\text { Core } \\
\text { length } \\
\mathrm{m}\end{array}$ & $\begin{array}{l}\text { Core } \\
\text { sample } \\
\text { interval } \\
(\mathrm{cm})\end{array}$ & $\begin{array}{l}\text { TBT } \\
\text { analysis }\end{array}$ & $\begin{array}{l}\text { Analytical } \\
\text { method for } \\
\mathrm{Cu}, \mathrm{Pb}, \mathrm{Zn}\end{array}$ & $\begin{array}{l}\text { LOI } \\
\text { wt } \%\end{array}$ & $\begin{array}{l}\mathrm{CaCO}_{3} \\
\mathrm{wt} \%\end{array}$ & $\begin{array}{l}\text { Dry density } \\
\left(\mathrm{g} \mathrm{cm}^{-3}\right)\end{array}$ \\
\hline Barton B. BART5 & $\begin{array}{l}52.7386 \\
1.4968\end{array}$ & 1999 & 1.75 & 0.73 & 1 & No & AAS & 18.8 & 74 & 0.20 \\
\hline Wroxham B. WROX2 & $\begin{array}{l}52.6990 \\
1.4191\end{array}$ & 2000 & 1.58 & 0.65 & 1 & Yes & AAS & 11.2 & 77 & 0.33 \\
\hline Salhouse B. SALG2 & $\begin{array}{l}52.6895 \\
1.4294\end{array}$ & 2003 & 1.50 & 0.86 & 1 & Yes & XRF & 14.7 & 51 & 0.25 \\
\hline $\begin{array}{l}\text { Ormesby Little B. } \\
\text { ORML1 }\end{array}$ & $\begin{array}{l}52.6703 \\
1.6449\end{array}$ & 2005 & 2.00 & 1.47 & 1 & No & XRF & 41.9 & 24 & 0.09 \\
\hline Hickling B. HICK1 & $\begin{array}{l}52.7389 \\
1.5763\end{array}$ & 2002 & 1.00 & 0.39 & 0.5 & Yes & AAS & 33.3 & 14 & 0.19 \\
\hline Sprat's Water SPRA1 & $\begin{array}{l}52.4661 \\
1.6873\end{array}$ & 2002 & & 1.41 & 1 & No & AAS & 15.9 & 76 & 0.19 \\
\hline Barnby B. BARB4 & $\begin{array}{l}52.4636 \\
1.6355\end{array}$ & 1998 & 0.3 & 1.23 & 1 & No & AAS & 23.3 & 70 & 0.11 \\
\hline Woolner's Carr WOOC1 & $\begin{array}{l}52.4646 \\
1.6839\end{array}$ & 2002 & 1.0 & 0.95 & 1 & No & AAS & 21.8 & 63 & 0.12 \\
\hline $\begin{array}{l}\text { Ormesby Great B. } \\
\text { ORMG2 }\end{array}$ & $\begin{array}{l}52.6862 \\
1.6490\end{array}$ & 2002 & 1.2 & 1.44 & 1 & No & AAS & 22.6 & 46 & 0.15 \\
\hline
\end{tabular}

The column TBT analysis indicates whether TBT was measured. Concentrations of organic matter (by loss on ignition, LOI), calcium carbonate (calculated from Ca as measured by XRF), and sediment dry density are averages for the post-1900 sediment

until about 1990, after which the concentration declines, abruptly at Salhouse Great Broad and Wroxham Broad, and more gently at Hickling Broad. In contrast to TBT, the metals are present throughout the sediment record. The $\mathrm{Pb}$ concentration shows a broad peak in the mid twentieth century, reaching a maximum at approximately 1950, and then declining to the present day. The present day concentrations are $\sim 50 \%$ of the maximum value, and similar in magnitude to the concentrations in sediment dating to 1900 . The concentration of $\mathrm{Pb}$ is not significantly different between heavily and lightly boated sites, either before or after $1960(p=0.34$, Table 3). Additionally, the ratio of post-1960 to pre-1960 mean $\mathrm{Pb}$ concentration (which provides a simple measure of general enrichment) is not significantly different between heavily and lightly boated sites (Table 4).

$\mathrm{Cu}$ and $\mathrm{Zn}$ broadly resemble $\mathrm{Pb}$ in showing a concentration increase through the first half of the twentieth century, but differ through the late twentieth century in that a concentration decline is weak or absent (Fig. 3). Before 1960 there is no significant difference between the heavily and lightly boated sites with respect to $\mathrm{Cu}$ or $\mathrm{Zn}$ concentration (Table 3). However, for both $\mathrm{Cu}$ and $\mathrm{Zn}$, the post 1960 sediment at heavily boated sites is significantly enriched, on average, relative to lightly boated sites ( $p=0.036$ and 0.020 for $\mathrm{Cu}$ and $\mathrm{Zn}$, respectively [Table 3]). This enrichment is stronger for $\mathrm{Cu}$ than for $\mathrm{Zn}$. The ratio of post-1960 over pre-1960 is 1.75 for $\mathrm{Cu}$ and 1.47 for $\mathrm{Zn}$. This difference in behaviour between $\mathrm{Cu}$ and $\mathrm{Zn}$ is seen more strongly in ratios between pre and post1960 concentrations (Table 4), which reveal a statistically significant increase for $\mathrm{Cu}$ only ( $p=0.038$ for $\mathrm{Cu}$, but 0.231 and 0.380 for $\mathrm{Zn}$ and $\mathrm{Pb}$, respectively). To test whether the relative increase in $\mathrm{Cu}$ and $\mathrm{Zn}$ enrichment coincides with the expansion of leisure boating, the motorboat count record was compared with the $\mathrm{Cu} / \mathrm{Pb}$ and $\mathrm{Zn} / \mathrm{Pb}$ ratios (Fig. 4). The $\mathrm{Cu} / \mathrm{Pb}$ ratio in heavily boated sites shows a distinct stepwise increase in the time interval 1955-1965, coincident with the period of most rapid expansion in leisure 

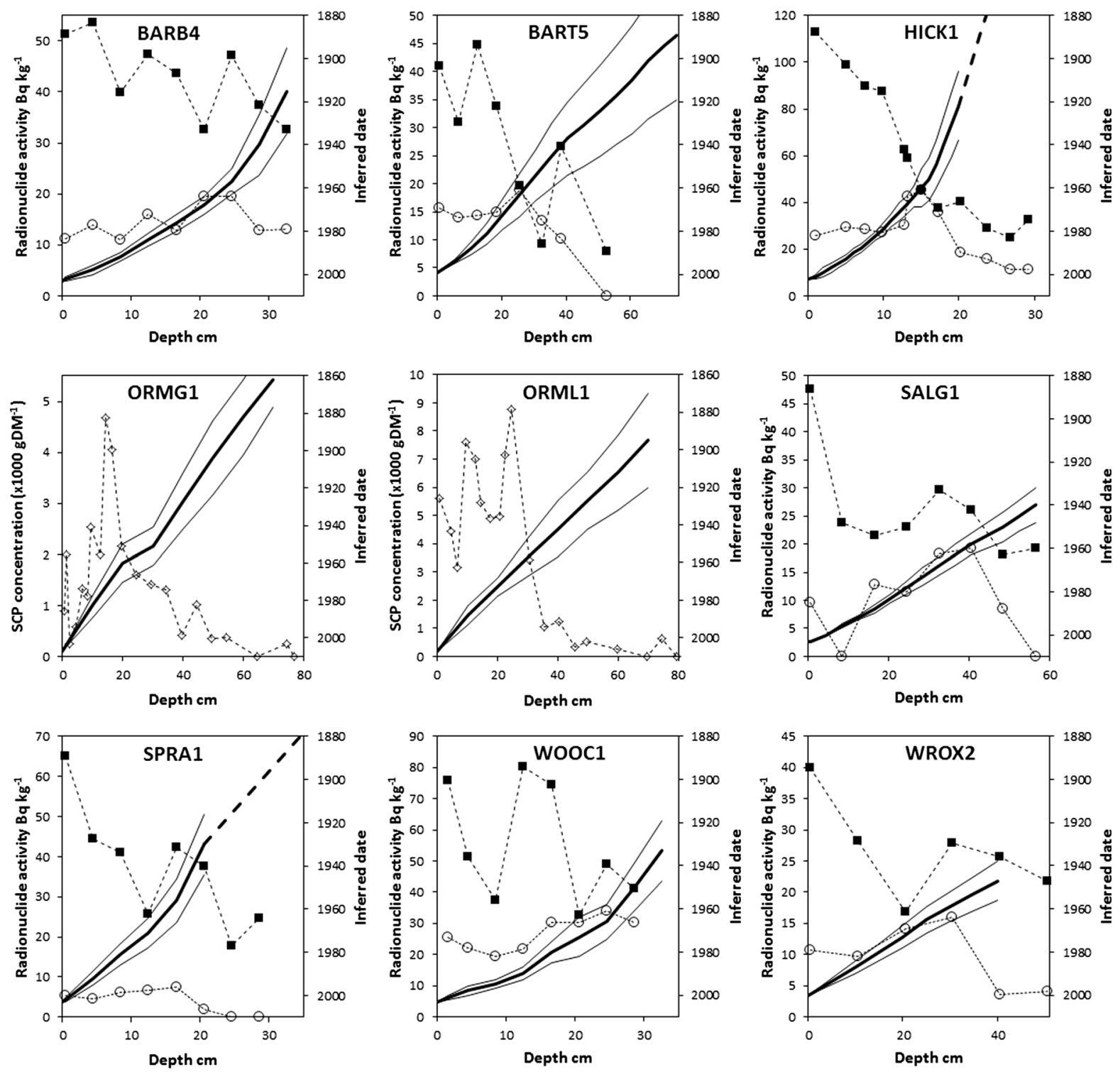

Fig. 2 Sediment age-depth models for all study lakes. ${ }^{210} \mathrm{~Pb}$ (total)—black squares; ${ }^{137} \mathrm{Cs}$-open circles; spheroidal carbonaceous particles_open diamonds. All ${ }^{210} \mathrm{~Pb}$ dating based on CRS model. Thick solid line: age model. Thin solid line: $1 \mathrm{sd}$

motorboats. After this step, the ratio continues to increase. The lightly boated sites do not show a corresponding step, but do show an increase in the later twentieth century in parallel with the records at the heavily boated sites. The $\mathrm{Zn} / \mathrm{Pb}$ ratio does not show a step-wise increase in any cores; rather the ratio shows a steady increase through the twentieth century at both heavily and lightly boated sites. uncertainty on age model. Thick dashed line: age model extrapolation based on assumed constant mass accumulation rate

\section{Discussion}

The sediment geochemical record

The twentieth century sediment record of contamination of these lakes by $\mathrm{Cu}, \mathrm{Pb}, \mathrm{TBT}$ and $\mathrm{Zn}$ reveals distinct differences among these contaminants, and in the case of $\mathrm{Cu}$, also a distinct difference between 
Table 2 Certified reference materials used for calibration and quality control for XRF measurements

CRM7002 Light sandy soil

GBW7309 Stream sediment

GBW7602 Bush, branches and leaves

GBW7603 Bush, branches and leaves

GBW7604 Poplar leaves

GBW7605 Tea

LGC6139 River clay sediment

NCSDC70302 Carbonate rock

NCSDC70309 Carbonate rock

NCSDC70314 Tibet sediment

NCSDC70317 Tibet sediment

NCSDC70319 Tibet sediment

NCSDC73301 Rock

NCSDC73302 Rock

NCSDC73303 Rock

NCSDC73309 Stream sediment

NCSDC73373 Stream sediment

NIST2709 San Joaquin Soil

heavily boated and lightly boated sites. Such a difference was also demonstrated by Hoare (2007) for TBT, by comparing lakes connected to and isolated from navigation in the Bure catchment. The pattern of variation can be interpreted in terms of two distinct sources of pollution in addition to any naturally occurring metal, one with a broad mid twentieth century maximum that is independent of boat activity, and another that is associated in both time and space with boat usage.

The sediment $\mathrm{Pb}$ enrichment record, characterised by a broad mid-twentieth-century maximum, is seen in all 9 studied lakes and shows no indication of a boat intensity signal. This pattern is typical of lakes across Britain (Foster and Charlesworth 1996; Yang and Rose 2005), and indeed a comparable signal has been reported elsewhere in the developed world (Cochran et al. 1998; Lepland et al. 2010). This is consistent with long-distance transport of atmospheric pollution from mixed urban and industrial sources (Yang and Rose 2005). Between-site differences in the $\mathrm{Pb}$ concentration show no systematic geographic pattern, and are likely associated with local factors related to sedimentation rate and focusing. Prior to 1960 this remote source also dominated the supply of $\mathrm{Cu}$ and $\mathrm{Zn}$ to all nine lakes, and even after 1960 contributed substantially to the sediment records, as seen in the rising $\mathrm{Cu} / \mathrm{Pb}$ and $\mathrm{Zn} / \mathrm{Pb}$ ratios at lightly as well as heavily boated sites, consistent with changing atmospheric emissions (National Atmospheric Emissions Inventory, http://naei.defra.gov.uk/overview/apoverview).

The previously reported association of TBT with the known history of its use in antifouling paints, here strengthened by the addition of new data (the Salhouse Great Broad core), is the most unambiguous evidence of a boating impact on contaminant concentrations. TBT does not occur in nature, and was little used except for the production of antifouling paints, so its origin from boating is certain. This is not the case for $\mathrm{Cu}$, which is used in a wide variety of industries, such that substantial contamination of the sediment took place in the early twentieth century prior to increases in boating intensity. Thus, any signal from antifouling paint contamination must be in the form of an enhancement above previous levels of pollution, and will coexist with the pollution record from continuing alternative sources. Despite these circumstances, which are to a large extent unfavourable for detection of an antifouling paint signal, we find a statistically significant spatial and temporal association of sediment $\mathrm{Cu}$ with boating intensity. We find sediment $\mathrm{Cu}$ enrichment to occur when two conditions are both met: (1) the lake must have been open to heavy boat traffic, and (2) the sediment must have been deposited during the period of high boating activity. This pattern of spatial and temporal variation is wholly consistent with a boat source for $\mathrm{Cu}$. Although this pattern does not prove a causal link, we have no alternative explanations. For $\mathrm{Zn}$, the situation is less clear. Boat intensity class is positively associated with sediment $\mathrm{Zn}$ concentration, but in contrast to $\mathrm{Cu}$, the ratio to $\mathrm{Pb}$ does not significantly increase with intensification of boat usage. For this reason we restrict further analysis to $\mathrm{Cu}$.

Procedures exist to distinguish natural from anthropogenic metal in lake sediment records (Hilton et al. 1985; Boyle 2001b; Boes et al. 2011), based on correlations between the metal and natural tracer elements. However, these cannot be applied to $\mathrm{Cu}$ at the study sites because none of the potential natural tracer elements show any correlation with $\mathrm{Cu}$ in the older sediment. We attribute this to a relatively high exposure of lakes to atmospheric pollution in eastern England, evidenced by a statistically significant 

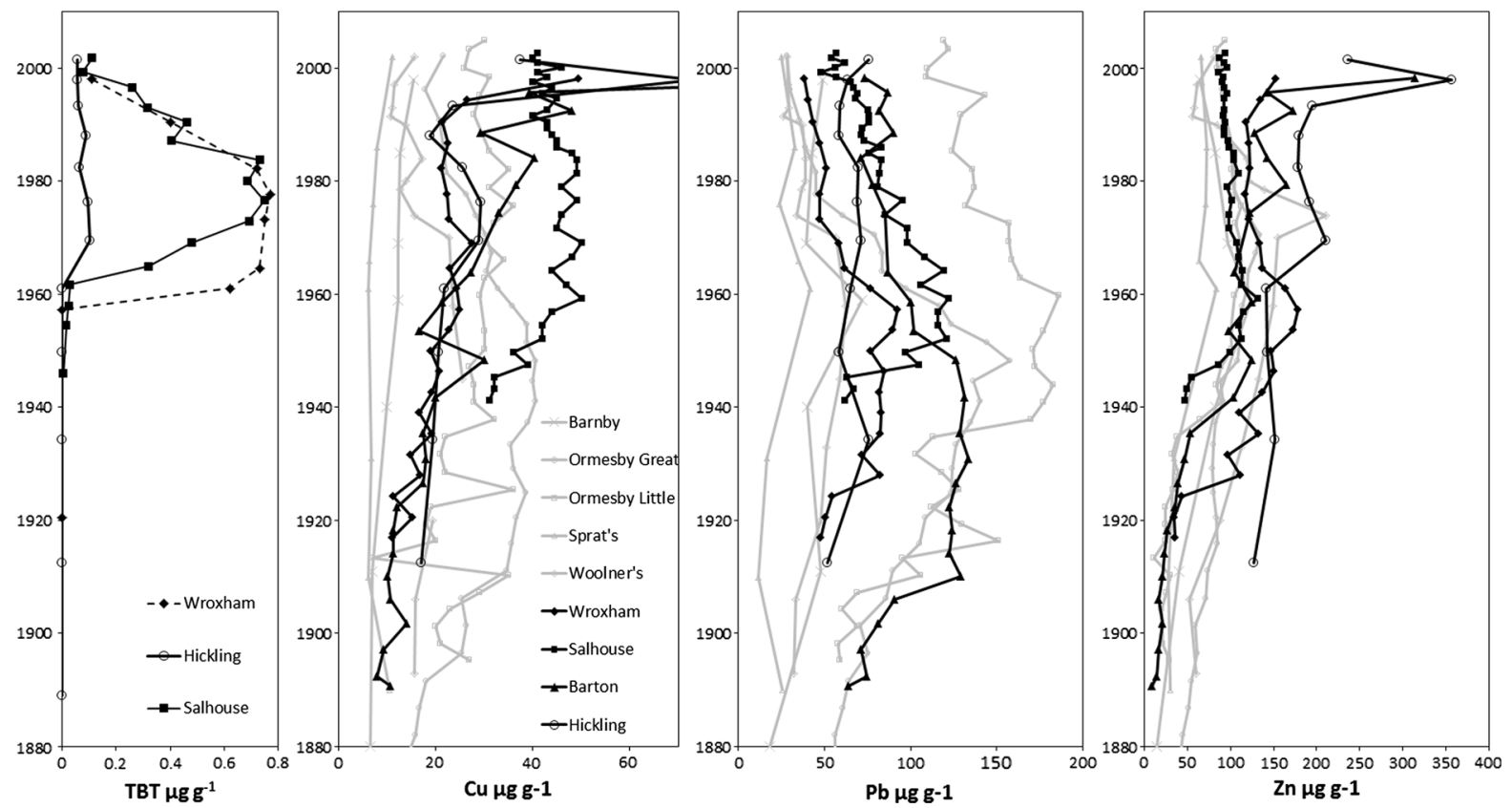

Fig. 3 Concentration (dry mass) data. For $\mathrm{Cu}, \mathrm{Pb}$ and $\mathrm{Zn}$ black lines—heavily boated sites; grey lines-lightly boated sites

correlation of $\mathrm{Cu}$ with $\mathrm{Pb}$ at all sites for the period prior to 1960 (Table 5). So, instead of applying a natural tracer, we use the past association of $\mathrm{Cu}$ with $\mathrm{Pb}$ to provide approximate estimates of both the natural and the $\mathrm{Pb}$ pollution-related contribution to the sediment total $\mathrm{Cu}$ concentration. This is achieved by regressing $\mathrm{Cu}$ against $\mathrm{Pb}$. We assume that the intercept provides a measure of the natural component (a slight underestimate because $\mathrm{Pb}$ will not naturally fall to zero), and that the regression model provides a measure of $\mathrm{Cu}$ associated with $\mathrm{Pb}$ pollution. This regression model also provides an estimate of $\mathrm{Cu}$ that is neither natural nor related to $\mathrm{Pb}$ pollution, a component we refer to as "excess" $\mathrm{Cu}$, and which provides a measure of any boating-related $\mathrm{Cu}$. We quantify post-1960 excess $\mathrm{Cu}$ by subtracting regression model $\mathrm{Cu}$ (trained on the pre-1960 data) from the measured post-1960 values. Because most of our $\mathrm{Cu}$ measurements are based on nitric acid extracts, our natural component neglects any inert mineral-bound $\mathrm{Cu}$. However, two of our sites (Ormesby Little Broad and Salhouse Great Broad) had Cu measured by XRF, which includes mineral-bound $\mathrm{Cu}$. For calculation of percentage natural contributions for these two sites, we substituted the mean natural $\mathrm{Cu}$ concentration of the other seven sites. Though not entirely satisfactory, neglecting these two sites does not affect our interpretation. Table 5 shows the percentage $\mathrm{Cu}$ contributions calculated in this way, of natural, $\mathrm{Pb}$-pollution related, and "excess" $\mathrm{Cu}$. Though only very approximate, these values suggest that about one-third of the sediment $\mathrm{Cu}$ is of natural origin, rather more is related to atmospheric $\mathrm{Pb}$ pollution, whereas $\mathrm{Cu}$ in excess of these two sources comprises $45 \%$ of the total at the heavily boated sites, and $13 \%$ at the lightly boated sites. We consider it likely that most of the excess $\mathrm{Cu}$ at the lightly boated sites is also of atmospheric origin, our estimate being biased by recent reductions in the $\mathrm{Cu} / \mathrm{Pb}$ ratio of atmospheric pollution (National Atmospheric Emissions Inventory, http://naei.defra.gov.uk/ overview/ap-overview).

\section{Environmental significance}

As discussed in the preceding section, our data analysis demonstrates that sediment $\mathrm{Cu}$ enrichment has taken place at the heavily boated broads. And, although this does not strictly prove a causal association, it is reasonable to suppose that a substantial proportion of the $\mathrm{Cu}$ originates from boat antifouling 
Table 3 Metal dry mass concentration summary statistics

\begin{tabular}{|c|c|c|c|c|c|c|c|}
\hline Site name and boating status (heavy or light) & $\mathrm{N}$ & $\mathrm{Cu} \mathrm{ppm}$ & SD & Zn ppm & SD & $\mathrm{Pb} \mathrm{ppm}$ & SD \\
\hline \multicolumn{8}{|l|}{ Post 1960} \\
\hline Wroxham $(\mathrm{H})$ & 10 & 23 & 2 & 130 & 15 & 52 & 11 \\
\hline Salhouse Great $(\mathrm{H})$ & 28 & 45 & 3 & 100 & 10 & 82 & 22 \\
\hline Barton $(\mathrm{H})$ & 8 & 36 & 7 & 140 & 24 & 83 & 6 \\
\hline Hickling $(\mathrm{H})$ & 6 & 25 & 4 & 183 & 24 & 66 & 6 \\
\hline Barnby (L) & 3 & 14 & 2 & 81 & 17 & 44 & 5 \\
\hline Ormesby Great (L) & 11 & 26 & 5 & 109 & 16 & 57 & 25 \\
\hline Ormesby Little (L) & 14 & 31 & 3 & 100 & 11 & 136 & 18 \\
\hline Sprat's Water (L) & 5 & 8 & 2 & 71 & 8 & 32 & 7 \\
\hline Woolner's Carr (L) & 10 & 14 & 4 & 109 & 50 & 35 & 9 \\
\hline Heavily boated $(\mathrm{H})$ & & 32.2 & 10.0 & 138.0 & 34.4 & 70.8 & 14.6 \\
\hline Lightly boated (L) & & 18.4 & 9.5 & 94.1 & 17.1 & 60.7 & 43.0 \\
\hline$T$ test for $\mathrm{H}>\mathrm{L}(\mathrm{P} 1$ tail $)$ & & 0.036 & & 0.020 & & 0.335 & \\
\hline \multicolumn{8}{|l|}{ Pre 1960} \\
\hline Wroxham $(\mathrm{H})$ & 12 & 18 & 4 & 113 & 51 & 75 & 15 \\
\hline Salhouse Great (H) & 9 & 31 & 3 & 42 & 20 & 53 & 24 \\
\hline Barton $(\mathrm{H})$ & 16 & 15 & 6 & 48 & 41 & 108 & 24 \\
\hline Hickling $(\mathrm{H})$ & 6 & 18 & 2 & 136 & 12 & 61 & 3 \\
\hline Barnby (L) & 4 & 9 & 3 & 65 & 48 & 45 & 22 \\
\hline Ormesby Great (L) & 25 & 28 & 11 & 72 & 24 & 94 & 37 \\
\hline Ormesby Little (L) & 21 & 25 & 7 & 48 & 32 & 124 & 45 \\
\hline Spratt's Water (L) & 3 & 8 & 2 & 30 & 4 & 18 & 7 \\
\hline Woolner's Carr (L) & 6 & 21 & 5 & 99 & 42 & 48 & 13 \\
\hline Heavily boated $(\mathrm{H})$ & & 20.5 & 7.4 & 84.9 & 46.8 & 74.3 & 24.3 \\
\hline Lightly boated (L) & & 18.2 & 9.3 & 62.8 & 25.8 & 65.7 & 42.6 \\
\hline$T$ test for $\mathrm{H}>\mathrm{L}(\mathrm{P} 1$ tail $)$ & & 0.353 & & 0.197 & & 0.366 & \\
\hline
\end{tabular}

A $t$ test reveals $\mathrm{Cu}$ and $\mathrm{Zn}$ have higher concentrations in the heavily boated than the lightly boated sites. Pb shows no difference

paint. We may also reasonably infer a disproportionate contribution of this boating component to $\mathrm{Cu}$ toxicity; whereas the other sources of $\mathrm{Cu}$ are active throughout the year, the antifouling paint contribution is intentionally maximal during the plant growing season, which coincides with minimum river discharge and thus maximum aqueous concentrations. We also have evidence from other studies that $\mathrm{Cu}$ contamination is associated with loss of charophyte species from UK lakes (Lambert and Davy 2011), and that in marine environments antifouling paints can release $\mathrm{Cu}$ at a rate sufficient to cause harm (Ytreberg et al. 2010). What we cannot do, with the information available from the lake sediment record, is directly calculate ecosystem exposure to $\mathrm{Cu}$. With reliable hydrological data for the lakes, and assuming that our single core sites provide unbiased estimates of the lake-wide average sediment $\mathrm{Cu}$ burial rate, we could calculate for each site the annual mean total water column $\mathrm{Cu}$ concentration. Unfortunately, reliable hydrological data are not generally available, so we can do no more than illustrate, for Hickling Broad, the approximate magnitudes. Hickling Broad has a surface area of $1.3 \mathrm{~km}^{2}$ and hydrological catchment of approximately $16 \mathrm{~km}^{2}$. Assuming a mean annual depthequivalent runoff rate of $0.21 \mathrm{~m} \mathrm{yr}^{-1}$ (Average for local Rivers Ant, Bure, Tud, Wensum and Yare, data from National River Flow Archive, CEH, UK), then the areal water load (total annual water through-put normalised to lake bed area) at Hickling Broad is $2.6 \mathrm{~m}^{3} \mathrm{~m}^{-2} \mathrm{yr}^{-1}$. Given a post-1960 sediment $\mathrm{Cu}$ burial flux of $11 \mathrm{mg} \mathrm{m}^{-2} \mathrm{yr}^{-1}$, the mean annual total $\mathrm{Cu}$ concentration is thus $4.2 \mu \mathrm{g} \mathrm{L}^{-1}$. This estimate must be regarded as speculative, but does precisely 
Table 4 Comparison of sediment $\mathrm{Cu}, \mathrm{Zn}$ and $\mathrm{Pb}$ concentrations before and after 1960

$\mathrm{Pb}$ shows little change; $\mathrm{Cu}$ and $\mathrm{Zn}$ both increase. $\mathrm{Cu}$ shows a greater increase in heavily boated than lightly boated sites

\begin{tabular}{llll}
\hline Ratio post 1960/pre 1960 mean concentration & & & \\
\hline Site name and boating status (heavy or light) & $\mathrm{Cu}$ & $\mathrm{Zn}$ & $\mathrm{Pb}$ \\
\hline Wroxham (H) & 1.3 & 1.2 & 0.7 \\
Salhouse Great (H) & 1.4 & 2.4 & 1.6 \\
Barton (H) & 2.4 & 2.9 & 0.8 \\
Hickling (H) & 1.4 & 1.4 & 1.4 \\
Barnby (L) & 1.5 & 1.2 & 1.0 \\
Ormesby Great (L) & 0.9 & 1.5 & 0.6 \\
Ormesby Little (L) & 1.2 & 2.1 & 1.1 \\
Sprat's water (L) & 1.0 & 2.3 & 1.8 \\
Woolner's Carr (L) & 0.5 & 0.6 & 0.6 \\
Heavily boated (H) & 1.7 & 2.0 & 1.1 \\
Lightly boated (L) & 1.0 & 1.6 & 1.0 \\
$T$ test for H $>$ L (p 1 tail) & 0.038 & 0.231 & 0.380 \\
\hline
\end{tabular}

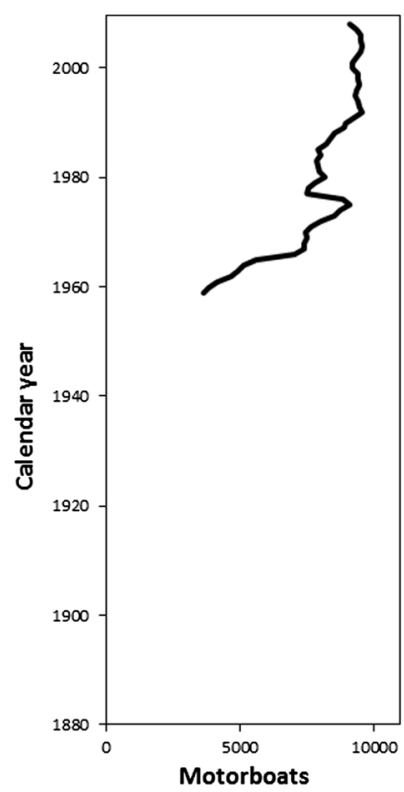

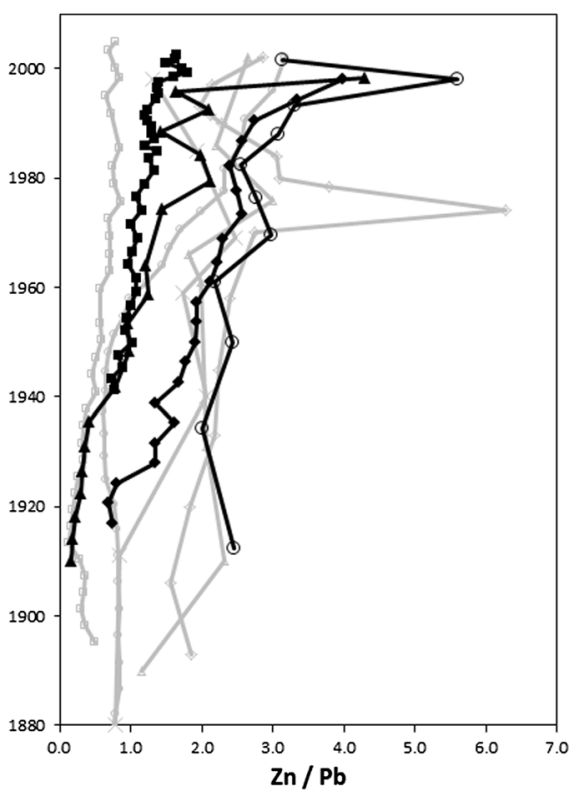

Fig. 4 Motorboat numbers and $\mathrm{Cu}$ and $\mathrm{Zn}$ ratios to $\mathrm{Pb}$. For $\mathrm{Cu} / \mathrm{Pb}$ and $\mathrm{Zn} / \mathrm{Pb}$ black lines-heavily boated sites; grey lines-lightly boated sites

match concentration values recorded in the field in 2005 (Lambert 2007). However, without a means for deciding the temporal distribution of $\mathrm{Cu}$ concentration through the year, there is no reliable basis for applying a more sophisticated metal toxicity model. Nonetheless, the magnitude is sufficient to suggest that environmental harm is likely, falling as it does within a range of $\mathrm{Cu}$ concentrations demonstrated to be harmful (Brix et al. 2005; Van Sprang et al. 2008). For freshwater systems this is particularly critical, as in aqueous media plants are directly exposed to the harmful effects of $\mathrm{Cu}$ and, thus, algae and some species of aquatic higher plants are more easily subjected to $\mathrm{Cu}$ toxicity (Gupta 1986; Jana and Choudhuri 1982; Fernandes and Henriques 1991). Carbohydrate synthesis was inhibited in the cyanobacterium Anacystis nidulans exposed to only $0.06 \mathrm{ppm}$ $\mathrm{Cu}$ (Gupta 1986), which is of the same order of magnitude predicted to be in the waters of Hickling Broad by this current study and recorded by Lambert in Hickling Broad in August 2005 (Lambert 2007). In further experiments Havens (1994) demonstrated that 
Table 5 Approximate source contribution to post-1960 sediment $\mathrm{Cu}$ concentration

\begin{tabular}{|c|c|c|c|c|}
\hline \multirow[t]{2}{*}{ Site name and boating status (heavy or light) } & \multirow[t]{2}{*}{ Regression of $\mathrm{Cu}$ on $\mathrm{Pb}\left(\mathrm{R}^{2}, p\right)$} & \multicolumn{3}{|c|}{ Source contribution $(\%)$} \\
\hline & & "Natural" & Pb-related & Excess \\
\hline Wroxham $(\mathrm{H})$ & $0.76,<0.001$ & 11 & 50 & 39 \\
\hline Salhouse Great $(\mathrm{H})$ & $0.81, \ll 0.001$ & 22 & 31 & 47 \\
\hline Barton $(H)^{\#}$ & $0.28,0.070$ & 4 & 31 & 64 \\
\hline Hickling $(\mathrm{H})$ & $0.76,<0.001$ & 39 & 32 & 29 \\
\hline Barnby (L) & $0.59,<0.001$ & 46 & 35 & 19 \\
\hline Ormesby Great (L) & $0.92, \ll 0.001$ & 27 & 50 & 24 \\
\hline Ormesby Little (L) & $0.32, \ll 0.001$ & 24 & 54 & 23 \\
\hline Sprat's water (L) & $0.33,0.008$ & 73 & 27 & 0 \\
\hline Woolner's Carr (L) & $0.78,<0.001$ & 17 & 83 & 0 \\
\hline Heavily boated average & - & 19 & 36 & 45 \\
\hline Lightly boated average & - & 37 & 50 & 13 \\
\hline
\end{tabular}

$\mathrm{Cu}$ is regressed on $\mathrm{Pb}$ for the pre-1960 sediment to estimate the "natural" (regression intercept) $\mathrm{Cu}$, and to establish a regression model on $\mathrm{Pb}$. This model allows "natural" and $\mathrm{Pb}$-related $\mathrm{Cu}$ to be subtracted from total $\mathrm{Cu}$ for the post-1960 period

\# Barton Broad regression is significant only at the $90 \%$ level

$\mathrm{Cu}$ at concentrations similar to those recorded by Lambert (2007) in the interstitial waters of Hickling Broad in 2005 (100-200 $\left.\mu \mathrm{g} \mathrm{l}^{-1}\right)$ reduced the biomass of zooplankton, ciliates, flagellates, and autotrophic phytoplankton. Bacterial biomass was increased by an order of magnitude relative to the controls.

It is thus evident that substantial ecological impacts may occur at $\mathrm{Cu}$ concentrations comparable to those arising from antifouling $\mathrm{Cu}$ contamination. So, although we have no direct evidence regarding the ecological impact of the antifouling paint in the Broads system, the indirect evidence for this, combined with the observation that sediment $\mathrm{Cu}$ enrichment at boated sites is demonstrable despite high background levels in the area, makes it likely that $\mathrm{Cu}$ from antifouling paints is causing harm. Legislation was put in place in 1987 to ban the use of TBT in antifouling paints for small boats $(<25 \mathrm{~m})$, and in 2001 further legislative measures were introduced in the UK to restrict usage of "booster biocide" antifouling agents in small $(<25 \mathrm{~m})$ vessel paints to dichlofluanid, zinc pyrithione and zineb (Cresswell et al. 2006), effectively banning the use of Irgarol 1051 and diuron. However, the use of $\mathrm{Cu}$ as an antifouling substitute for TBT remains unregulated and widely practiced. Our finding of a strong association of $\mathrm{Cu}$ with boating, with $\mathrm{Cu}$ at levels consistent with environmental harm, suggests a high risk that current legislation is not providing adequate protection to freshwater ecosystems such as the Broads and other inland lakes and wetland systems.

\section{Conclusions}

The TBT sediment record for Salhouse Great Broad shows a rapid concentration increase after ca. 1960, followed by a decline ca. 1990, the same temporal signal as previously reported for Hickling Broad and Wroxham Broad. This further supports the interpretation that TBT from boat antifouling paints rapidly contaminated waterways that are connected to the river system, the contamination only declining following the TBT ban in 1987. Pb, a metal not associated with antifouling paints, peaks in the early to mid twentieth century, and is no more enriched at heavily boated than at lightly boated sites. This is consistent with a dominant atmospheric pathway, sourced from remote urban and industrial areas. $\mathrm{Cu}$ and $\mathrm{Zn}$ show similar behaviour to $\mathrm{Pb}$ prior to 1960 ; the concentrations increase with time and show no difference between lightly and heavily boated sites. However, for the sediment deposited after 1960, the average concentrations are significantly greater in the heavily boated broads. In the case of within-site temporal variations, $\mathrm{Cu}$ shows enhancement after the increase in 
boating intensity, but $\mathrm{Zn}$ does not. The $\mathrm{Cu} / \mathrm{Pb}$ ratio most clearly reveals the stepped character of this $\mathrm{Cu}$ increase, the step coinciding in time with a rapid increase in motorboat use in the region between 1955 and 1965. The observed metal concentration data are consistent with two distinct pollution sources. First, $\mathrm{Pb}$ with some $\mathrm{Zn}$ and $\mathrm{Cu}$ is derived via an atmospheric pathway, peaking during the mid twentieth century and declining to the present day. This component changes in composition through the record, the $\mathrm{Cu} / \mathrm{Pb}$ and $\mathrm{Zn} / \mathrm{Pb}$ ratios increasing through the last 50 years. Second, TBT and $\mathrm{Cu}$ are derived from a local source associated with levels of motorboat activity. This component appears after ca. 1955, and rises rapidly before stabilising after 1970 . The TBT contamination declines after 1990, whereas $\mathrm{Cu}$ either maintains its level or increases. $\mathrm{Zn}$ does not show the same strength of association with boating; if a boating signal is indeed present, then it is effectively masked by alternative sources of $\mathrm{Zn}$.

We consider it likely that present day exposure of the Broads ecosystem to antifouling paint $\mathrm{Cu}$ is sufficient to cause ecological harm. If so, then current regulations that permit the use of $\mathrm{Cu}$ in antifouling paints do not provide adequate protection to the Broads ecosystem and may hinder ecological recovery. The same may be expected at other boated freshwater ecosystems around the world.

Acknowledgments We thank Andrea Kelly and the Broads Authority for funds to support metals and dating analysis of most of the sediment cores. The Suffolk Broads research was supported by English Nature (now Natural England), Contract No. NB/T/806/02-04.445. The dating and TBT analysis of Salhouse Great Broad was funded from the University of London Central Research Fund (ref AR/ATF/B).

Open Access This article is distributed under the terms of the Creative Commons Attribution 4.0 International License (http:// creativecommons.org/licenses/by/4.0/), which permits unrestricted use, distribution, and reproduction in any medium, provided you give appropriate credit to the original author(s) and the source, provide a link to the Creative Commons license, and indicate if changes were made.

\section{References}

Appleby PG, Nolan PJ, Gifford DW, Godfrey MJ, Oldfield F, Anderson NJ, Battarbee RW (1986) ${ }^{210} \mathrm{~Pb}$ dating by low background gamma counting. Hydrobiologia 143:21-27

Ayres K, Sayer CD, Perrow M, Skeate E (2008) The contribution of palaeolimnology to shallow lake management: an example from Upton Great Broad, Norfolk, UK. Biodivers Conserv 17:2153-2168

Boes X, Rydberg J, Martinez-Cortizas A, Bindler R, Renberg I (2011) Evaluation of conservative lithogenic elements ( $\mathrm{Ti}$, $\mathrm{Zr}, \mathrm{Al}$, and $\mathrm{Rb}$ ) to study anthropogenic element enrichments in lake sediments. J Paleolimnol 46:75-87

Boyle JF (2000) Rapid elemental analysis of sediment samples by isotope source XRF. J Paleolimnol 23:213-221

Boyle J (2001a) Redox remobilization and the heavy metal record in lake sediments: a modelling approach. J Paleolimnol 26:423-431

Boyle JF (2001b) Inorganic geochemical methods in palaeolimnology. In: Last WM, Smol JP (eds) Tracking environmental change using lake sediments. Volume 2: physical and geochemical methods. Kluwer, Dordrecht, pp 83-141

Brix KV, DeForest DK, Burger M, Adams WJ (2005) Assessing the relative sensitivity of aquatic organisms to divalent metals and their representation in toxicity datasets compared to natural aquatic communities. Hum Ecol Risk Assess 11:1139-1156

Callow ME, Callow JA (2002) Marine biofouling: a sticky problem. Biologist 49:10-14

Cochran JK, Hirschberg DJ, Wang J, Dere C (1998) Atmospheric deposition of metals to coastal waters (Long Island Sound, New York U.S.A.): evidence from saltmarsh deposits. Estuar Coast Shelf Sci 46:503-522

Cresswell T, Richards JP, Glegg GA, Readman JW (2006) The impact of legislation on the usage and environmental concentrations of Irgarol 1051 in UK coastal waters. Mar Pollut Bull 52:1169-1175

Dahl B, Blanck H (1996) Toxic effects of the antifouling agent Irgarol 1051 on periphyton communities in coastal water microcosms. Mar Pollut Bull 32:342-350

Dowson PH, Bubb JM, Lester JN (1994) The effectiveness of the 1987 retail ban on TBT based antifouling paints in reducing butyltin concentrations in East Anglia, UK. Chemosphere 28:905-910

Eklund B, Elfström M, Gallego I, Bengtsson BE, Breitholtz M (2010) Biological and chemical characterization of harbour sediments from the Stockholm area. J Soils Sediment 10:127-141

Eklund B, Johansson L, Ytreberg E (2014) Contamination of a boatyard for maintenance of pleasure boats. J Soils Sediment 14:955-967. doi:10.1007/s11368-013-0828-6

Evans LC (2004) Factors affecting the distribution and abundance of the submerged macrophyte community in Hickling Broad, Norfolk: is boating activity having an adverse impact? MSc Thesis, University College London

Fent K, Hunn J (1991) Phenyltins in water, sediment, and biota of freshwater marinas. Environ Sci Technol 25:956-963

Fernandes JC, Henriques FS (1991) Biochemical, physiological, and structural effects of excess copper in plants. Bot Rev 57:246-273

Foster IDL, Charlesworth SM (1996) Heavy metals in the hydrological cycle: trends and explanation. Hydrol Process 10:227-261

George M (1992) The land use, ecology and conservation of Broadland. Packard Publishing Limited, UK

Gupta SL (1986) Copper uptake and inhibition of growth, photosynthetic pigments and macromolecules in the 
cyanobacterium Anacystis nidulans. Photosynthetica 20:447-453

Havens KE (1994) Structural and functional responses of a freshwater plankton community to acute copper stress. Environ Pollut 86:259-266

Hilton J, Davison W, Ochsenbein U (1985) A mathematical model for analysis of sediment core data-implications for enrichment factor calculations and trace-metal transport mechanisms. Chem Geol 48:281-291

Hoare, DJ (2007) Ecological change in shallow lakes through antifoulant biocide contamination. $\mathrm{PhD}$ Thesis, University of London

Holmes J, Sayer CD, Liptrott E, Hoare DJ (2010) Complex controls on ostracod faunal palaeoecology in a shallow, coastal brackish-water lake: implications for palaeosalinity reconstruction. Freshw Biol 55:2484-2498

Jana S, Choudhuri MA (1982) Senescence in submerged aquatic angiosperms-effects of heavy metals. New Phytol 90:477-484

Lambert SJ (2007) The ecological tolerance limits of British (UK) stoneworts (Charophytes). PhD Thesis, University of East Anglia, Norwich

Lambert SJ, Davy AJ (2011) Water quality as a threat to aquatic plants: discriminating between the effects of nitrate, phosphate, boron and heavy metals on charophytes. New Phytol 189:1051-1059

Lambert SJ, Thomas KV, Davy AJ (2006) Assessment of the risk posed by the antifouling booster biocides Irgarol 1051 and diuron to freshwater macrophytes. Chemosphere 63:734-743

Lepland A, Andersen TJ, Lepland A, Arp HPH, Alve E, Breedveld GD, Rindby A (2010) Sedimentation and chronology of heavy metal pollution in Oslo harbor, Norway. Mar Pollut Bull 60:1512-1522

Livingston DA (1955) A lightweight piston sampler for lake deposits. Ecology 36:137-139

Madgwick G, Emson D, Sayer CD, Willby NJ, Rose N, Jackson MJ, Kelly A (2011) Centennial-scale changes to the aquatic vegetation structure of a shallow eutrophic lake and implications for restoration. Freshw Biol 56:2620-2636

Maguire RJ, Tkacz RJ, Chau YK, Bengert GA, Wong PTS (1986) Occurrence of organotin compounds in water and sediment in Canada. Chemosphere 15:253-274

Marcheselli M, Conzo F, Mauri M, Simonini R (2010) Novel antifouling agent-Zinc pyrithione: short- and long-term effects on survival and reproduction of the marine polychaete Dinophilus gyrociliatus. Aquat Toxicol 98:204-210

Moss B (2001) The Broads. Collins, London
Parks R, Donnier-Marechal M, Frickers PE, Turner A, Readman JW (2010) Antifouling biocides in discarded marine paint particles. Mar Pollut Bull 60:1226-1230

Patmore IR, Sayer CD, Goldsmith B, Davidson TA, Rawcliffe R, Salgado J (2014) Big Ben: a new wide bore piston corer for multi-proxy paleolimnology. J Paleolimnol 51:79-86

Rose NL (1994) A note on further refinements to a procedure for the extraction of carbonaceous fly-ash particles from sediments. J Paleolimnol 11:201-204

Rose NL (2008) Quality control in the analysis of lake sediments for spheroidal carbonaceous particles. Limnol Oceanogr Methods 6:172-179

Rose NL, Harlock S, Appleby PG, Battarbee RW (1995) Dating of recent lake sediments in the United Kingdom and Ireland using spheroidal carbonaceous particle (SCP) concentration profiles. Holocene 5:328-335

Sayer CD, Hoare DJ, Simpson GL, Henderson ACG, Liptrot ER, Jackson MJ, Appleby PG, Boyle JF, Jones JI, Waldock MJ (2006) TBT causes regime shift in shallow lakes. Environ Sci Technol 40:5269-5275

Smith DC (2003) The population ecology of charophytes in the context of shallow lake restoration. PhD Thesis, University of East Anglia, Norwich

Thomas KV, Brooks S (2010) The environmental fate and effects of antifouling paint biocides. Biofouling 26:73-88

Tsunemasa N, Yamazaki H (2014) Concentration of antifouling biocides and metals in sediment core samples in the northern part of Hiroshima Bay. Int J Mol Sci 15:9991-10004

Van Sprang P, Vangheluwe M, Van Hyfte A, Heijerick M, Vandenbroele M, Verdonck F (2008) Chapter 3.2 environmental effects. In: Voluntary risk assessment of copper, copper II sulphate pentahydrate, copper (I) oxide, copper (II) oxide, dicopper chloride trihydroxide. European Union Risk Assessment Report, European Chemicals Agency, 179 pp

Voulvoulis N, Scrimshaw MD, Lester JN (2000) Occurrence of four biocides utilized in antifouling paints, as alternatives to organotin compounds, in waters and sediments of a commercial estuary in the UK. Mar Pollut Bull 40:938-946

Waldock MJ, Waite ME (1994) The performance of an analytical method for determination of TBT during a 6-year monitoring program. Appl Organomet Chem 8:649-658

Yang H, Rose N (2005) Trace element pollution records in some UK lake sediments, their history, influence factors and regional differences. Environ Int 31:63-75

Ytreberg E, Karlsson J, Eklund B (2010) Comparison of toxicity and release rates of $\mathrm{Cu}$ and $\mathrm{Zn}$ from anti-fouling paints leached in natural and artificial brackish seawater. Sci Total Environ 408:2459-2466 